\title{
The development of a project-based student worksheet to foster fourth graders' creativity in integrated theme learning
}

\author{
Sofyan Aris ${ }^{1}$ \\ Alben Ambarita ${ }^{2}$ \\ Rochmiyati ${ }^{3}$ \\ ${ }^{1}$ Master's Program in Primary Education, Universitas Lampung, Bandar Lampung, Indonesia \\ 2,3 Department of Primary Education, Universitas Lampung, Bandar Lampung, Indonesia
}

\begin{abstract}
The goal of this study was to find out if a student worksheet, which was based on project-based learning, was valid in terms of improving learning outcomes. Research and development (R\&D) was employed as the method, which was carried out until the initial product design development stage. Purposive sampling was employed involving 22 students in class IV at SD Negeri 7 Metro Barat as the experimental class and 23 students in class IV at SD Negeri 3 Metro Barat as the control class. A validation questionnaire was utilised to collect data. The percentage method and descriptive analysis were utilised in the data analysis. The project-based learning student worksheet was declared valid to improve learning outcomes based on the results of an expert validation test (87.5\%) on content, an expert validation test ( $80 \%)$ on construction, and an expert validation test $(100 \%)$ on language. The implications of the findings are also discussed along with suggestions for further research.
\end{abstract}

\section{KEYWORDS}

Student worksheet; projectbased learning; student creativity

Received: 1 February 2022 Accepted: 9 February 2022 Published: 11 February 2022

\section{Introduction}

Curriculum development is one way to improve the quality of the competitiveness of human resources. Indonesia implements the 2013 curriculum which began to be implemented in the 2013 school year in schools designated by the government and schools that are ready to implement it. There are several important things from changing or improving the curriculum, namely students are more required to be active, creative, communicative and innovative in solving problems they face at school. The learning model is one of the tools so that the 2013 curriculum can be achieved. Project based learning (Pjbl) is one model that is in accordance with the demands in the application of the 2013 curriculum (Febriana, 2017). Project based learning (PJBL) is a systematic learning model, and involves students in learning knowledge and skills. This is of course through a lengthy and structured search/excavation process, towards authentic and complex questions, and carefully designed tasks and products.

In addition to the 2013 curriculum learning model, it needs to be supported by teaching materials. Mulyasa (2006) suggests that teaching materials are one part of teaching resources which can be interpreted as something that contains learning messages, both specific and general in nature that can be used for learning purposes. One type of teaching material used in the teaching and learning process in public elementary schools in the West Metro subdistrict is in the form of student activity sheets (LKPD). Widjajanti (2008) said the student activity sheet (LKPD) is one of the learning resources that can be developed by educators as facilitators in learning activities.

Teaching materials in the form of LKPD become one of the important components in improving student learning outcomes. Purwanto (2002) states that factors that can affect the process and learning outcomes include external factors such as environmental and instrumental factors, while internal factors consist of physiological factors (physical condition and the five senses) and psychological factors (talent, interest, intelligence, motivation, cognitive ability), in this case the LKPD used by educators in public elementary schools in the West Metro District is still limited and does not provide space for students to improve learning outcomes.

Based on the analysis of learning needs in nine public elementary schools in the west metro sub-district, in general, the obstacles faced by nine educators in grade IV at the metro west elementary school are the same. These constraints relate to the ability and willingness of educators to make teaching materials that can improve student learning outcomes. On the other hand, some educators still do not understand the project based learning model. In addition, based on the information obtained, it shows that the learning outcomes of students are still low so far. Educators also expressed the need to develop LKPD based on project-based learning models that are detailed, easy to understand, attractive and easy to use to accommodate the improvement of student learning outcomes. This is in line 
with Arikunto (2006) which states that there are many factors that can affect learning outcomes in every learning, these factors are changing the way of teaching, the quality of the design, the evaluation model and the use of teaching materials in the learning process. Therefore, it is necessary to develop project-based teaching materials that can improve student learning outcomes.

Based on the explanation above, this study aims to determine the validity of the LKPD product based on the project based learning model in order to improve student learning outcomes.

\section{Literature review Student worksheet}

LKPD is defined as a printed teaching material in the form of sheets of paper containing material, summaries, and instructions for implementing learning tasks that must be done by students with reference to the basic competencies (KD) that must be achieved (Prastowo, 2012). This is in accordance with the definition of LKPD according to Trianto (2010). The Student Activity Sheet (LKPD) is a student guide that is used to develop cognitive aspects as well as a guide to the development of all aspects of learning in the form of a guide to inquiry or problem solving activities according to indicators of achievement of learning outcomes. to be achieved. According to Depdiknas (2008), LKPD (student worksheet) are sheets containing tasks that must be done by students, usually in the form of instructions, steps to complete a task by referring to the Basic Competencies (KD) that will be achieved.

The Student Activity Sheet (LKPD) has several benefits, which were stated by Wulandari (2013) stating that the role of LKPD is very large in the learning process because it can increase student activity in learning and its use in learning can help teachers to direct their students to find concepts concepts through their own activities. The existence of LKPD gives a considerable influence in the learning process so that the preparation of LKPD must meet various requirements. Salirawati (2004) mentions three requirements for an LKPD to be said to be feasible, namely didactic requirements, construction requirements, and technical requirements. The didactical requirements relate to the fulfillment of the principles of effective learning in an LKPD. Construction requirements are related to language. Technical requirements are related to writing based on predetermined rules.

\section{Project-based learning}

Project-based learning (PjBL) is a learning method with a constructivist approach that leads to problem solving efforts. Constructivism gives independence to students to plan and carry out their own learning or collaborate under the coordination of the teacher (Doppelt, 2003). Efforts are made to build the independence of students in learning can be done through the application of PjBL in the learning process. PjBL as a constructivist learning is learning with real problem situations so that it can give birth to permanent knowledge and is a learning model that can organize projects in learning (Giilbahar \& Tinmaz, 2006) .

The results of research conducted by Schneider et al. (2002) stated that the implementation of PjBL succeeded in improving the performance of students during learning. According to Widiyatmoko \& Pamelasari (2012), project-based learning is a relevant learning by involving aspects of the environment in which students are located and learning by involving the creativity that exists within students. PjBL strategy on learning achievement is expressed by Thomas (2000) that PjBL emphasizes education that provides opportunities for a learner-centered learning system, collaborative and integrates real and practical problems, effective teaching in building knowledge, creativity and able to improve results study.

\section{Learning outcomes}

Learning Outcomes are the impact of learning activities. According to Sukmadinata (2007) that learning outcomes are the realization or expansion of potential skills or capacities possessed by a person. According to (Dimyati \& Mudjiono, 2006), learning outcomes are things that can be viewed from two sides, namely the students' side from the teacher's side. From the side of students, learning outcomes are a better level of mental development when compared to before learning. The level of mental development is manifested in the types of cognitive, affective, and psychomotor domains. Meanwhile, from the teacher's point of view, learning outcomes are when the learning materials are completed. The learning outcomes obtained by students are of different levels, many factors can affect learning outcomes. Arikunto (2006) states that there are factors that can be changed such as teaching methods, quality of design, evaluation models, and others, there are also factors that must be accepted as they are such as: student background, salary, school environment. According Raresik (2016) the factors that influence student learning outcomes include internal factors (factors from within students), external factors (factors from outside students) and factors from the school.

\section{Methods}

The development procedure in this study refers to the theory proposed by Borg \& Gall (1983). This procedure was chosen because it has detailed but simple steps. Research The development of the Borg \& Gall model has the following steps: 1) research and information gathering, 2) planning, 3) development of the initial form of the product), 4) Desk Evaluation, 5) main product revision, 6) main field trial, 7) operational product revision, 8) operational field test, 9) final product revision, and 10) dissemination and implementation. 
In accordance with the ten steps of implementing research and development, in this study the researcher only carried out steps one to seven, namely Research and information gathering (introduction) to revision of Operational products (final product based on input from the main field test). Steps eight to ten were not carried out due to time constraints and expensive costs for developing research products and this was indeed carried out in accordance with research standards for thesis needs.

\section{Participants}

Determination of research subjects using purposive sampling technique. This research was conducted in class IV at SD Negeri 7 Metro Barat with 22 students as the experimental class and SD Negeri 3 Metro Barat with 23 students as the control class.

\section{Instruments}

The data collection technique used in this study was using a validation questionnaire conducted by experts. Furthermore, the questionnaire was given to material experts, linguists and media experts. Data collection activities are obtained based on aspects that have been observed based on predetermined assessment indicators.

\section{Data analysis}

The analysis of the product validation results that have been carried out is calculated using the formula:

$$
\mathbf{N}=\frac{\mathbf{R}}{\mathrm{SM}} \mathbf{X} 100
$$

Table 1. Criteria for the validity of student worksheets

\begin{tabular}{cl}
\hline Presentation & \multicolumn{1}{c}{ Interpretation } \\
\hline $81 \%-100 \%$ & Very valid, very thorough, usable \\
$61 \%-80 \%$ & Quite Valid, quite effective, can be used \\
& with Minor Improvements \\
$41 \%-60 \%$ & Less valid, less effective, incomplete, \\
& $\begin{array}{l}\text { unused } \\
21 \%-40 \%\end{array}$ \\
Invalid, ineffective, incomplete, unusable \\
$0 \%-20 \%$ & $\begin{array}{l}\text { Very invalid, very ineffective, very } \\
\text { incomplete, unusable }\end{array}$ \\
\hline
\end{tabular}

(Akbar, 2013)

\section{Results}

The LKPD that is developed must go through the validation of content/material experts as a form of evaluation of the content/materials as well as the presentation of the products that have been developed. The data obtained in the form of quantitative and qualitative data through a questionnaire given by researchers to experts. Validation activities are carried out after product development. Product validation includes content, construction and language validation carried out by three expert tests using a validation questionnaire. The results of expert validation are shown in Table 2 below.

Table 2. Expert validation results and teacher responses

\begin{tabular}{clcc}
\hline No & Aspect & Percentage & Criteria \\
\hline $\mathbf{1}$ & Contents & $87.5 \%$ & Valid \\
$\mathbf{2}$ & Construction & $80 \%$ & Valid \\
$\mathbf{3}$ & Language & $100 \%$ & Valid \\
\hline
\end{tabular}

\section{Discussion}

The LKPD that is developed must go through the validation of content/material experts as a form of evaluation of the content/materials as well as the presentation of the products that have been developed. Questionnaires are given to validators to see the validity of the content/material, and the product being developed. Based on the calculation of the questionnaire data obtained from the validation obtained a percentage of $87.5 \%$ with valid criteria. Like the validation of the contents of the LKPD that is developed, it must go through construct validation. Based on the calculation of the questionnaire data obtained from the validation obtained by $80 \%$ with valid criteria. Then the results of expert validation obtained a $100 \%$ percentage of the language stating that LKPD based on Project Based Learning is communicative and easy to understand by students. Correct use of punctuation and grammar. The sentences used are effective and do not cause plural or ambiguous meanings. Based on the description of the results 
of the validation stage above, the results of the validation of the contents, constructs, and language of Project Based Learning-based student worksheets are valid to use.

The product of LKPD development based on Project Based Learning is produced, the content of the material is related to the daily life of students, so it is easy to understand and integrated with Project Based Learning steps. The development of LKPD based on Project Based Learning adapts to the knowledge dimensions proposed by Anderson \& Krathwohl (2001) namely factual, conceptual, and procedural knowledge.

The factual, conceptual, and procedural dimensions adapted to the LKPD aim to combine knowledge from simple to more complex knowledge. This is in line with several research results (Widiyatmoko \& Pamelasari, 2012) concluding that the impact of student learning outcomes on Project Based Learning-based education has an important role in students' understanding of the development of existing learning. Ambarwangi \& Suharto (2014) concluded that learning using pictures can improve learning outcomes and students' intelligence. Because the use of images in LKPD is the basis for the formation of learning outcomes in education.

\section{Conclusion}

Based on the results of the study, validation results were obtained from three experts and two teachers on content, construct and language. The results by experts (87.5\%) on content, (80\%) on construction, and (100\%) on language stated that student worksheets based on project based learning were declared valid to improve student learning outcomes.

Several limitations in this study, including core competencies and basic competencies in Project Based Learning-based LKPD only developed one sub-theme with six lessons, sample limitations and effectiveness testing and different tests were only carried out in one school, product trials were only for six meetings or one subthemes, so that the possibility of learning outcomes is not optimal, then the learning outcomes measured in this study are only in the cognitive domain. Then the results studied were only three indicators, namely providing simple explanations, building basic skills, and concluding.

\section{Acknowledgments}

The researchers would like to thank the University of Lampung for supporting them to conduct this research.

\section{Funding}

This research did not receive a specific grant from any funding agency in the public, commercial, or not-forprofit sector.

\section{References}

Akbar, S. (2013). Learning tool instruments. Bandung: Rosdakarya.

Ambarwangi, S., \& Suharto, S. (2014). Reog as means of students' appreciation and creation in arts and culture based on the local wisdom. Harmonia: Journal Of Arts Research And Education. 14 (1), 37-45.

Anderson, LW, et al. (2001). A Taxonomy for learning, teaching, and assessing: A revision of bloom's taxonomy of educational. New York: Longman.

Arikunto. (2006). Research procedures a practical approach. Jakarta: Rineka Cipta.

Bell, Stephanie. (2010). Project-based learning for the 21st century: skills for the future. Clearing House, 83:39-43. Taylor \& Francis Group

Borg, WR \& Gall, MD. (1983). Edication research: An introduction fifth edition. New York: Longman.

Dimyati, \& Mudjiono. (2006). Learning and Learning. Jakarta: PT Rineka Cipta.

Doppelt, Y. (2003). Implementation and Assessment of Project-Based Learning in a Flexible Environment. International Journal of Technology and Design Education 13, 255-272. https://doi.org/10.1023/A:1026125427344

Febriana, R. (2017). The Effectiveness of project based learning on students' social attitudes and learning outcomes. Journal of Technology and Vocational Education. 23(4). 374-382.

Giilbahar, Y., \& Tinmaz, H. (2006). Applying project-based learning and e-portfolio assessment in undergraduate programs. Journal of Technology Research in Education. 38(3): 309-327.

Mulyasa. (2006). Becoming a professional teacher creating creative and fun learning. Bandung: PT Teen Rosdakarya Publisher.

Ministry of National Education. (2008). Guidelines for the development of teaching materials. Jakarta: Education Department National.

Ngalim, Purwanto. (2002). Theoretical and practical education science. Bandung: Teenagers Work.

Prastowo, A. (2018). learning resources and learning resource centers: theory and its application in schools/madrasahs. Jakarta: Rineka Cipta.

Raresik, Kd. Ayuning, Dibia, I Kt., \& Widiana, I Wyn. (2016). Analisis faktor-faktor yang mempengaruhi hasil belajar bahasa indonesia pada siswa kelas V SD gugus VI. e-Journal PGSD Universitas Pendidikan Ganesha. 4(1), 1-11.

Salirawati, D. (2006). Preparation and use of LKS in the learning process. Paper presented at Community Service Activities, UNY Yogyakarta.

Schneiders, AA. (1955). personal adjustment and mental health. New York: Holt, Rinehart and Winston.

Sukmadinata, \& Syaodih, Nana. (2007). Educational Research Methods. Bandung: Rosdakarya.

Thomas, J. W. (2000). A review of research on project-based learning. San Rafael, CA: Autodesk Foundation.

Trianto. (2010). Integrated learning models, concepts, strategies and its implementation in KTSP. Jakarta: Earth Literacy. 
Widjajanti, E. (2008). Quality of student worksheets. In Seminar Papers on the preparation of LKS for Vocational High School/MAK teachers in Community Service Activities, Department of Education, Faculty of Mathematics and Natural Sciences, Yogyakarta State University. Proceeding International Conference on Educational Research and Evaluation (ICERE) (pp. 2-5).

Widiyatmoko, A., \& Pamelasari, SD. (2012). Project-based learning to develop science teaching aids using used materials. Indonesian Journal of Science Education. 1(1). 51-56.

Wulandari, Y. (2013). The effectiveness of project-based learning on quadrilateral materials on mathematical connections and selfconfidence in junior high school students. Doctoral Dissertation. Semarang State University. 